\title{
A New Method for Measuring the Free Thyroid Hormone in Human Serum and an Analysis of the Factors That Influence Its Concentration*
}

\author{
Sidney H. Ingbar, $†$ Lewis E. Braverman, Nancy A. Dawber, and \\ GLEN N Y. LeE \\ (From the Thorndike Memorial Laboratory and the Second and Fourth [Harvard] Medical \\ Services, Boston City Hospital and the Department of Medicine, Harvard Medical \\ School; and the St. Elizabeth's Hospital and Department of Medicine,
}

Tufts Medical School, Boston, Mass.)

There exists a great deal of evidence that it is the free or unbound portion of the circulating thyroid hormone that is accessible to the tissues and physiologically active, whereas the great majority of the hormone, which is protein bound, serves as a metabolically inert reservoir (1-4). If this is the case, then the concentration of free hormone in the plasma must be a major determinant of both the metabolic effectiveness and the rate of removal of the thyroid hormone in the blood.

Despite the probable importance of the free thyroid hormone, few reports have dealt with its measurement in the plasma. Certain methods for directly measuring the proportion of free thyroxine $\left(\mathrm{T}_{4}\right)$ in serum appear to have either technical or theoretical disadvantages $(5,6)$, although others have not been completely evaluated (7). On the other hand, there has been described a variety of methods, such as in vitro red blood cell or resin uptake techniques, which reflect the proportion of free thyroid hormone in the serum, but do not directly measure this function (8-11). Consequently, the absolute concentration of free hormone in serum cannot be calculated from such re-

* Submitted for publication April 2, 1965 ; accepted June 30, 1965.

Supported in part by research grants AM-00267 and AM-07917 from the National Institute of Arthritis and Metabolic Diseases, and by grant FR-76 from the Division of Research Facilities and Resources, National Institutes of Health, Bethesda, Md.

Presented in part at the Annual Meeting of the American Federation for Clinical Research, May 3, 1964, Atlantic City, N. J.

† Address requests for reprints to Dr. Sidney H. Ingbar, Thorndike Memorial Laboratory, Boston City Hospital, Boston, Mass. 02118. sults, even though the total concentration of hormone in the serum is known.

The present report describes and evaluates a method for measuring the proportion of free thyroid hormone in serum that appears to be either simpler or more nearly indicative of the true value for this function than methods previously described. Both the proportion and absolute concentration of free $T_{4}$ in the serum of normal and abnormal patients have been determined and the causes of abnormal values in disease states evaluated. In addition, the proportion of free $3,5,3^{\prime}-\mathrm{L}-$ triiodothyronine $\left(\mathrm{T}_{3}\right)$ in normal serum has been measured. A preliminary description of the method and certain of the results obtained have appeared in abstract form (12).

\section{Methods}

Theoretical considerations. Theoretically, the per cent of free $\mathrm{T}_{4}{ }^{1}$ in the serum should be relatively simple to measure by equilibrium dialysis or ultrafiltration techniques. As has been recognized previously $(5,6)$, however, commercial preparations of $\mathrm{I}^{181}$-labeled $\mathrm{T}_{4}$ invariably are contaminated with sufficient radioactive iodide to preponderate over the free $I^{131}-T_{4}$ that passes the semipermeable membrane. Several methods have been described to meet or circumvent this problem $(5,6)$. As will be discussed below, these methods apparently have intrinsic difficulties. Therefore, a new method was sought for separating $\mathrm{I}^{131}-\mathrm{T}_{4}$ from $\mathrm{I}^{131}$-iodide in equilibrium dialyzates of serum enriched with commercial labeled $T_{4}$. This method sought to take advantage of the very properties of $\mathrm{I}^{131}-\mathrm{T}_{4}$ and $\mathrm{I}^{131}$-iodide that create analytic difficulties during the initial equilibrium dialysis. Thus, if the equilibrium dialyzate containing $\mathrm{I}^{131}-\mathrm{T}_{4}$ and $\mathrm{I}^{131}$-iodide is

1 In the present report, for purposes of brevity, the proportion of free $T_{4}$ in serum, expressed as a per cent of the total, will be termed $\mathrm{PFT}_{4}$; the absolute concentration of free $\mathrm{T}_{4}$ will be termed $\mathrm{AFT}_{4}$. 
mixed with an equal volume of normal plasma and this mixture (equilibrium dialyzate-plasma, EDP) is itself subjected to dialysis, labeled $\mathrm{I}^{-}$should be almost entirely free to diffuse into the dialyzate, whereas labeled $T_{4}$ should be almost entirely retained by the EDP within the dialysis sac. Simple dialysis would not remove $\mathrm{I}^{130}$-iodide from the EDP completely, however, since labeled $\mathrm{I}^{-}$is slightly bound by serum proteins (13). Complete removal of $\mathrm{I}^{130}$-iodide should be achieved, however, by suspending an anion exchange resin in the buffer against which the EDP is dialyzed. Iodide dialyzed from the EDP would be absorbed to the resin and, in this way, a diffusion gradient for iodide would be maintained until all labeled $\mathrm{I}^{-}$had been cleared from the EDP. Because of the intense association between $T_{4}$ and the proteins in the EDP, however, only negligible quantities of $\mathrm{I}^{131}-\mathrm{T}_{4}$ should become available to the resin during the time required to free the EDP of iodide.

Procedures. The method ultimately developed for measuring the $\mathrm{PFT}_{4}$ in serum consists of two parts : $a$ ) a technique for obtaining an equilibrium dialyzate of the test serum enriched with $\mathrm{I}^{131}$-labeled hormone, and $b$ ) a resin dialysis technique for freeing the equilibrium dialyzate of radioactive $\mathrm{I}^{-}$so that its content of labeled hormone can be determined accurately. The first half of the method, equilibrium dialysis of serum, is a modification of that described by Sterling and Hegedus (5). The procedure employed was similar in most respects to that used by these workers, except that acid washing and soaking of dialysis tubing were not performed. Such treatment was found to lead not infrequently to small leaks in the tubing that produced spurious increases in measured values for the free $T_{4}$. Instead, dialyses were performed in tubing 2 that had been washed thoroughly in distilled water and soaked for 30 to 60 minutes in 0.07 $\mathrm{M}$ sodium phosphate buffer, $\mathrm{pH} 7.4$ (standard phosphate buffer) before use. The method employed is as follows :

1) When labeled $T_{4}$ arrives from a commercial source, ${ }^{3}$ it is immediately made up in $5 \%$ human serum albumin (HSA) to a concentration of approximately $160 \mu \mathrm{c}$ per $\mathrm{ml}$. This solution can usually be stored in the refrigerator or freezer for 1 week without excessive deterioration.

2) To $6.0 \mathrm{ml}$ of the serum to be tested is added $25 \mu 1$ of the labeled $\mathrm{T}_{4}$ in HSA. This is allowed to stand for a short period. At the usual specific activity of the commercial $I^{131}-T_{4}$, this increases the $T_{4}$ concentration of the sample by approximately $2 \mu \mathrm{g}$ per $100 \mathrm{ml}$.

3) Five $\mathrm{ml}$ of the test serum containing labeled $T_{4}$ is pipetted into a dialysis sac. This is then sealed, care being taken to avoid contaminating the outside of the sac.

4) The dialysis sac is rinsed briefly under running tap water and is placed inside a $40-$ or $50-\mathrm{ml}$ cellulose nitrate centrifuge tube containing $5.0 \mathrm{ml}$ of standard phosphate buffer. The tube is tightly sealed, and its lower portion is inserted into a shaking water bath at $37^{\circ} \mathrm{C}$ for 20 hours.

2 Visking casing, $23 \mathrm{~mm}$ in diameter, Union Carbide Corp., Chicago, Ill.

3 Obtained from Abbott Laboratories, Oak Ridge, Tenn.
5) After dialysis is complete, $3.0 \mathrm{ml}$ of the dialyzate is pipetted into a test tube, and $3.0 \mathrm{ml}$ of any serum or plasma is added (indifferent plasma; outdated blood bank plasma may be used). Two $\mathrm{mg}$ of $\mathrm{KI}$ is added, and the contents of the tube are mixed thoroughly. This constitutes the equilibrium dialyzate-plasma mixture (EDP).

6) Five $\mathrm{ml}$ of the EDP is pipetted into a dialysis sac, which is then sealed.

7) The sac containing the EDP is placed into a cellulose nitrate centrifuge tube containing $17 \mathrm{ml}$ of standard phosphate buffer and $17 \mathrm{ml}$ of Amberlite IRA-400 anion exchange resin previously equilibrated with the same buffer.4

8) The tube is tightly sealed and is placed on a rotating mixer.

9) After 2 hours, the tube is removed from the mixer, the sac removed and opened, and $3.0 \mathrm{ml}$ of its contents pipetted into a counting tube (counting sample A).

10) From the original test serum, $100 \mu 1$ is pipetted into a counting tube, and the volume is brought to $3.0 \mathrm{ml}$ (counting sample B).

With each group of determinations a sample from a large pool of normal serum is analyzed. Additional specimens ("correction standards") are run in order to correct both for $\mathrm{I}^{131}$-iodide added to the test serum as a contaminant and for osmotic dilution of the EDP during resin dialysis. These are prepared as follows:

1) To $6.0 \mathrm{ml}$ of a $1: 1$ mixture of standard phosphate buffer and indifferent serum or plasma are added $25 \mu 1$ of $\mathrm{I}^{131}-\mathrm{T}_{4}$ in $\mathrm{HSA}$ and $2.0 \mathrm{mg}$ of $\mathrm{KI}$.

2) One hundred $\mu \mathrm{l}$ is pipetted into a counting tube, and the volume is brought to $3.0 \mathrm{ml}$ (counting sample $\mathrm{C}$ ).

3) Five $\mathrm{ml}$ is pipetted into a dialysis sac, which is then sealed.

4) The sac is placed inside a cellulose nitrate centrifuge tube containing $17 \mathrm{ml}$ of standard phosphate buffer and $17 \mathrm{ml}$ of IRA-400 resin. The tube is sealed and placed in a rotating mixer for 2 hours.

5) After this period, the sac is removed from the tube and opened. One hundred $\mu 1$ of its contents is pipetted into a counting tube, and the volume is made to $3.0 \mathrm{ml}$ (counting sample D).

Correction factors. To obtain maximal accuracy, it is necessary to correct for several sources of error. First, since the commercial preparation of $\mathrm{I}^{131}-\mathrm{T}_{4}$ is invariably contaminated with $\mathrm{I}^{131}$-iodide, which is later removed from the equilibrium dialyzate, it is necessary that the counting rate of the standard used in calculating the final $\mathrm{PFT}_{4}$ not include counts added to the test serum as iodide. Secondly, osmotic dilution of the EDP occurs during the resin dialysis procedure. This decreases the concentration of $\mathrm{I}^{131}-\mathrm{T}_{4}$ remaining in the EDP and lowers calcu-

\footnotetext{
$4 \mathrm{By}$ means of a pipette from which the tip has been removed, a suspension of resin in buffer is transferred into a $50-\mathrm{ml}$ graduated centrifuge tube. This process is continued until the volume of the sedimented resin is $17 \mathrm{ml}$. The volume of the supernatant buffer is then adjusted to an additional $17 \mathrm{ml}$, and the entire contents are then transferred to the cellulose nitrate centrifuge tube.
} 
lated values for $\mathrm{PFT}_{4}$. Both of these difficulties are overcome, however, by utilizing a correction standard. A sample of plasma is diluted with buffer to simulate an EDP, labeled $T_{4}$ is added, and the mixture is subjected to resin dialysis. Since both osmotic dilution and complete removal of iodide occur, the counting ratio of pre- to postdialysis specimens always exceeds unity and constitutes a factor that corrects for both osmotic dilution and contamination of the original $\mathrm{I}^{131}-\mathrm{T}_{4}$ with $\mathrm{I}^{131}$-iodide. ${ }^{5}$

Let $\mathrm{cpm}_{\mathbf{A}}, \mathrm{cpm}_{\mathbf{B}}, \mathrm{cpm}_{\mathrm{C}}$, and $\mathrm{cpm}_{\mathrm{D}}$ represent the radioactivity in counting samples $A, B, C$, and $D$, respectively. $\mathrm{Cpm}_{\mathrm{A}} \times 5 / 1.5=$ total free $\mathrm{I}^{131}-\mathrm{T}_{4}$ in equilibrium with test serum. $\mathrm{Cpm}_{\mathrm{B}} \times 50=$ total $\mathrm{I}^{131}$ added to test serum. 100 $\times\left(\mathrm{cpm}_{\Delta} \times 5 / 1.5\right) /\left(\mathrm{cpm}_{\mathrm{B}} \times 50\right)=\mathrm{PFT}_{\mathbf{4}} \quad$ (uncorrected $)$. $\mathrm{Cpm}_{\mathrm{C}} / \mathrm{cpm}_{\mathrm{D}}=$ correction factor for osmotic dilution and $\mathrm{I}^{131}$-iodide contamination. $\mathrm{PFT}_{4}$ (uncorrected) $\times \mathrm{cpm}_{\mathrm{C}} /$ $\mathrm{cpm}_{\mathrm{D}}=\mathrm{PFT}_{4}{ }^{6}$ Absolute concentration of free $\mathrm{T}_{4}=$ protein-bound iodine (PBI) $\times \mathrm{PFT}_{4} / 0.65$ (millimicro-

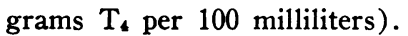

Electrophoretic methods. In many cases, a sample of the serum containing the labeled $T_{4}$ that was used for measurement of the free $T_{4}$ was subjected to filter paper electrophoresis in Tris-maleate buffer, $\mathrm{pH} 8.6$, by methods previously described (4). The distribution of such small quantities of $\mathrm{I}^{13 x}-\mathrm{T}_{4}$ is believed to reflect the approximate apportionment of endogenous $\mathrm{T}_{4}$-binding proteins in serum.

Miscellaneous methods. Values for serum PBI were performed by a modification of the method of Zak (14). Statistical analyses were performed according to methods described by Snedecor (15).

Patient material. Sera in the normal group were obtained from donors whose ages ranged between 2 and 84 years. Sera from patients in various abnormal categories were obtained from patients in the wards or outpatient clinics of the Boston City Hospital or St. Elizabeth's Hospital. Sera were quickly separated from clotted blood and were kept frozen until used.

5 The extent of dilution of the EDP during resin dialysis treatment was directly assessed by measuring the $\mathrm{OD}_{280}$ of the EDP before and after treatment. In 115 pairs of samples, optical density ratios averaged $1.095 \pm$ 0.040 (mean $\pm \mathrm{SD}$ ). The validity of utilizing such ratios was verified in other experiments in which $\mathrm{I}^{131}$-labeled HSA, previously freed of $\mathrm{I}^{131}$-iodide, was added to several EDP. Ratios of $\mathrm{OD}_{230}$ and of $\mathrm{I}^{131}$ in pre- and postresin dialysis specimens agreed closely.

6 Values obtained with this calculation and presented in the present report are only half those described in Reference 12 , since values therein were based on the total free $T_{4}$ in the entire system, rather than the total free $T_{4}$ in the dialysis sac. As pointed out to the authors by Dr. George C. Schussler, the concentration of free $T_{4}$ at equilibrium will be a function only of the binding interaction within the sac and, within broad limits, will be independent of the volume outside the sac. Therefore, the pertinent quantity of the free $T_{4}$ is not that within the entire system, but only that within the sac where the interaction of free with protein-bound $T_{4}$ occurs.
In the patients with hyper- or hypothyroidism, diagnoses were based upon clinical examination and upon values for serum $\mathrm{PBI}$ and thyroid radioactive iodine uptake and, occasionally, of basal metabolic rate. Patients designated as having nonthyroid illness ("sick patients") comprised a group with malignancy, myocardial or cerebral infarction, severe infection, and other severe acute or chronic systemic disorders.

\section{Results}

Evaluation of the resin dialysis procedure. Initial experiments were performed to determine the efficacy of the resin dialysis procedure in eliminating $\mathrm{I}^{131}$-iodide from the EDP. In these experiments, $3.0 \mathrm{ml}$ of standard phosphate buffer was mixed with an equal volume of human plasma to prepare a simulated EDP. This mixture was enriched with $20 \mu \mathrm{c}$ of inorganic $\mathrm{I}^{131}$ and $2.0 \mathrm{mg}$ of $\mathrm{KI}$ and subjected to the resin dialysis treatment. In 18 experiments, an average of $99.85 \%$ of the added $\mathrm{I}^{131}$-iodide was removed from the EDP (range, 99.30 to $99.96 \%$ ). Prolongation of the resin dialysis treatment or transfer of the sac containing the EDP to another tube for a second resin dialysis treatment did not appreciably improve the removal of $\mathrm{I}^{131}$-iodide from the EDP. Removal of labeled $\mathrm{I}^{-}$appeared to decrease slightly (never to less than $99.30 \%$ ) as the solution of $\mathrm{I}^{131}$-iodide employed aged progressively after arrival from a commercial source. In these instances, prior addition of thiouracil, cysteine, or ascorbic acid reduced the quantity of $\mathrm{I}^{131}$-iodide retained in the EDP. In two experiments in which large quantities of $\mathrm{I}^{131}$-iodide $(100 \mu \mathrm{c})$ were employed, chromatography of the EDP after resin dialysis treatment revealed a small radioactive peak at the origin and no radioiodine in the iodide zone, suggesting that $\mathrm{I}^{131}$ that had not been removed from the EDP was firmly bound to the plasma proteins. Very likely this represented an actual iodination of the proteins by oxidized products in the $\mathrm{I}^{\mathbf{1 3 1}}$ iodide employed.

Additional experiments were performed to determine whether significant losses of labeled $T_{4}$ from the EDP would occur during the resin dialysis procedure. To accomplish this, it was necessary either to eliminate completely or to ascertain correctly the proportion of the $\mathrm{I}^{131}$-iodide with which the preparation of $\mathrm{I}^{131}-\mathrm{T}_{4}$ was contaminated. Three methods were used. First, filter paper chro- 
matography was employed to determine the proportion of $\mathrm{I}^{131}$-iodide contaminating the $\mathrm{I}^{131}-\mathrm{T}_{4}$ added to the simulated EDP, and calculated values for recovered radioactive $T_{4}$ were corrected for this contamination. In other experiments, preparative paper chromatography of the commercial $\mathrm{I}^{131}-\mathrm{T}_{4}$ was performed. With the aid of radioautographs, the $\mathrm{I}^{131}-\mathrm{T}_{4}$ zone was excised, and small segments thereof were eluted directly into the simulated EDP. This was then subjected to the resin dialysis treatment. In the third series of experiments, serum was obtained from three patients given an intravenous injection of commercial $\mathrm{I}^{131}$ $\mathrm{T}_{4}$ several days earlier. Since previous studies have shown that $\mathrm{I}^{\mathbf{1 3 1}}$-iodide and other labeled products of deterioration of $\mathrm{I}^{131}-\mathrm{T}_{4}$ are removed from the blood more quickly than $\mathrm{I}^{131}-\mathrm{T}_{4}$ itself, the radioactive $T_{4}$ given to the patients would have been purified biologically (16). In these experiments, $3.0 \mathrm{ml}$ of the patients' sera was mixed with $3.0 \mathrm{ml}$ of phosphate buffer to simulate the EDP, and this mixture was then subjected to the resin dialysis treatment. In all three types of experiments, totaling 14 in number, an average of $99.9 \%$ (range, 99.4 to $104.0 \%$ ) of $\mathrm{I}^{131}-\mathrm{T}_{4}$ was recovered in the EDP after the resin dialysis procedure.

Experiments were also performed to determine the extent to which $\mathrm{T}_{\mathbf{3}}$ would be lost from the EDP during the resin dialysis treatment. In four experiments, recovery of chromatographically purified $\mathrm{T}_{3}$ from a simulated EDP after resin dialysis averaged $97.2 \%$ (range, 95.7 to $98.8 \%$ ).

Evaluation of the equilibrium dialysis method. A variety of experiments was performed to evaluate the characteristics of the system for equilibrium dialysis of the test serum. In the system described by Sterling and Hegedus (5), to which the present system closely adhered, distribution equilibrium for free $T_{4}$ was achieved in 16 hours. In the present studies, successive values of $\mathrm{PFT}_{4}$ obtained at 16,20 , and 24 hours in equilibrium dialyzates of the same serum were virtually identical, indicating that equilibrium had been achieved.

Sterling and Hegedus also reported that negligible quantities of $\mathrm{I}^{131}-\mathrm{T}_{4}$ were lost by adsorption to either the dialysis sac or to the wall of the cellulose nitrate tube in which equilibrium dialysis had been performed (5). This conclusion was based on calculation of the total recovery of $I^{131}$ and necessitated estimation of the volume of fluid both within and outside the dialysis sac at the completion of dialysis, a procedure in which accuracy of measurement must necessarily be limited. In the present studies, an alternative method was employed. To enhance the accuracy of counting, serum was enriched with several times the usual concentration of $\mathrm{I}^{131}-\mathrm{T}_{4}$. At the end of 16,20 , and 24 hours of dialysis, the entire tube and its contents were counted by a clinical scintillation probe. The contents of the tube were then removed, the tube was rinsed three times quickly, but thoroughly, with distilled water, and the empty tube was counted. Thereafter, a solution of $1 \%$ HSA was introduced into the tube and allowed to stand for 15 minutes. The tube was then emptied, rinsed thoroughly, and counted again. In three experiments, between 15 and $20 \%$ of the initial total radioactivity was found affixed to the tube after the distilled water wash. No difference between the quantity of $\mathrm{I}^{131}$ adsorbed to the tube at 16,20 , and 24 hours could be detected. This radioactivity was largely removed by $1 \% \mathrm{HSA}$, indicating that it had been reversibly adsorbed to the surface of the tube. Thus, it appears that although significant quantities of $T_{4}$ within the dialysis system became adsorbed to the tube in which equilibrium dialysis is performed, the entire contents of the dialysis system came into equilibrium within 16 hours. In other experiments, it was found that adsorption of $\mathrm{I}^{131}-\mathrm{T}_{4}$ from the dialyzate was not decreased by treating the cellulose nitrate tube with silicone, or by using a glass tube, whether or not it had been siliconized.

A third series of experiments was performed to ascertain the effects of dilution of the test serum upon the measured values of $\mathrm{PFT}_{4}$. A pool of fresh normal serum was, enriched with $\mathrm{I}^{131}-\mathrm{T}_{4}$ and serial dilutions with standard phosphate buffer, ranging between $1: 5$ and $1: 300$, were prepared. Samples of whole and dilute sera were then analyzed for $\mathrm{PFT}_{4}$ by the method described above. Values for the actual $\mathrm{PFT}_{4}$ in each specimen were divided by the dilution factor. This calculation is equivalent to that employed by Oppenheimer, Squef, Surks, and Hauer to obtain an estimate of the $\mathrm{PFT}_{4}$ in undiluted specimens from analyses of dilute specimens (6). As this calculation has been thought to correct for the effects of dilution, the resulting values will be termed "corrected" values for $\mathrm{PFT}_{4}$. 
In four experiments, corrected values for $\mathrm{PFT}_{4}$ calculated in this manner were consistently influenced by dilution. Dilutions of $1: 5$ resulted in corrected values for $\mathrm{PFT}_{4}$ that were approximately $55 \%$ of those obtained in undiluted sera. With further dilution, however, corrected values for $\mathrm{PFT}_{4}$ did not decrease further (Figure 1).

Reproducibility of the method. In 11 consecutive analyses of a pool of normal serum, values for $\mathrm{PFT}_{4}$ averaged $0.049 \pm 0.005$ (mean $\pm \mathrm{SD}$ ). In another pool of serum, 12 consecutive analyses yielded values for $\mathrm{PFT}_{4}$ that averaged $0.051 \pm$ 0.003 . In a single experiment, concomitant analysis for $\mathrm{PFT}_{4}$ in quintuplicate samples yielded values within the narrow range of 0.049 to 0.051 .

Values in various clinical states (Table I). In 105 normal patients ranging in age between 2 and 84 years, values for $\mathrm{PFT}_{4}$ averaged $0.050 \pm$ 0.009 (mean $\pm \mathrm{SD}$ ). In 21 patients with myxedema, values were significantly decreased, averaging $0.037 \pm 0.010$. Here, however, considerable variability and overlap with the normal range was evident. Values for $\mathrm{PFT}_{4}$ in 7 of the 21 patients with myxedema were within $1 \mathrm{SD}$ of the normal mean. A more consistent decrease in $\mathrm{PFT}_{4}(0.026$ \pm 0.006 ) was observed in 14 patients with normal pregnancy. As anticipated, the mean value for $\mathrm{PFT}_{4}(0.111 \pm 0.072)$ was significantly increased in 44 patients with thyrotoxicosis. Although great variability was evident in the extent of increase,

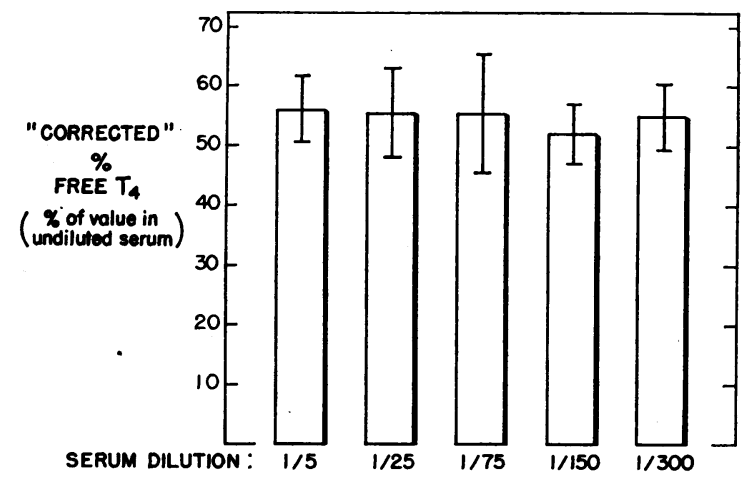

Fig. 1. Effect of diluting Serum on calculated ("CORRECTED") VALUES FOR THE PROPORTION OF FREE THYROXINE (PFT 4 ). In diluted serum, corrected per cent of free $T_{4}$ was obtained by dividing the measured value for $\mathrm{PFT}_{4}$ by the dilution factor, a calculation analogous to that employed by Oppenheimer and colleagues (6). Values shown represent mean \pm standard deviation of results in four separate experiments.
TABLE I

The per cent $\left(P F T_{4}\right)$ and absolute concentration $\left(A F T_{4}\right)$ of free thyroxine, and the protein-bound iodine $(P B I)$ in the serum of normal patients and of patients with various abnormal states*

\begin{tabular}{|c|c|c|c|}
\hline Diagnosis & $\mathrm{PFT}_{4}$ & PBI & AFT ، \\
\hline Normal & $\begin{array}{c}\% \text { total } \\
0.050 \pm 0.009 \\
(105)\end{array}$ & $\begin{array}{c}\mu g / 100 \mathrm{ml} \\
5.4 \pm 0.8 \\
(87)\end{array}$ & $\begin{array}{c}m \mu g / 100 m l \\
4.03 \pm 1.08 \\
(87)\end{array}$ \\
\hline Myxedema & $\underset{(21)}{0.037} \underset{0.010 \dagger}{ \pm}$ & $\underset{(21)}{1.6 \pm 0.5 \dagger}$ & ${ }_{(21)}^{0.88 \pm}{ }^{0.52 \dagger}$ \\
\hline Pregnancy & $0.026 \pm 0.006 \dagger$ & $\begin{array}{c}8.0 \pm 0.9 \dagger \\
(12)\end{array}$ & $\underset{(12)}{3.21 \pm 0.56 \dagger}$ \\
\hline Thyrotoxicosis & $0.11 \pm \underset{(44)}{0.072 \dagger}$ & $\begin{array}{c}12.9 \pm 2.9 \dagger \\
(43)\end{array}$ & $\begin{array}{c}20.56 \pm 13.07 \dagger \\
(43)\end{array}$ \\
\hline Sick & $0.078 \pm 0.033 \dagger$ & $\begin{array}{c}4.6 \pm 1.4 \ddagger \\
(22)\end{array}$ & $\begin{array}{c}5.12 \pm 2.998 \\
(22)\end{array}$ \\
\hline
\end{tabular}

* Values presented represent mean \pm standard deviation. Numbers in parentheses indicate number of observations in different patients. t Significance of difference from normal value, $p<0.001$. Significance of difference from normal value, $\mathrm{p}<0.025$.

Significance of difference from normal value, $p<0.050$

values within $1 \mathrm{SD}$ of the normal mean were found in only seven. A significant increase in $\mathrm{PFT}_{4}$ was also evident in patients with severe nonthyroidal illness in whom values averaged $0.078 \pm 0.033$. Overlap with values in both the normal and thyrotoxic range was seen in this group.

Values for $\mathrm{AFT}_{4}$ in normal subjects averaged $4.03 \pm 1.08 \mathrm{~m} \mu \mathrm{g}$ per $100 \mathrm{ml}$. A significant decrease was evident in patients with myxedema, largely as a result of the low concentration of hormone in the serum, although low values for $\mathrm{PFT}_{4}$ were also contributory. In accord with the findings of Sterling and Hegedus (5), but contrary to the findings of Oppenheimer and colleagues (6), mean values for $\mathrm{AFT}_{4}$ in the sera of pregnant women $(3.21 \pm 0.56)$ were significantly less than normal, although individual values in the two groups overlapped considerably. In keeping with the findings of other workers (5-7), values for $\mathrm{AFT}_{4}$ were consistently increased in patients with thyrotoxicosis, often strikingly so. In patients with nonthyroidal illness, a slight, but significant, increase in the mean $\mathrm{AFT}_{4}(5.12 \pm 2.29)$ was also seen; however, this increase was not so great as the increase in $\mathrm{PFT}_{4}$, since values of the $\mathrm{PBI}$ in this group were significantly subnormal. This increase in $\mathrm{AFT}_{4}$ in sick patients is in accord with the findings of Oppenheimer and colleagues (6), but does not agree with the findings of Sterling and Hegedus (5), whose patients may have been less seriously ill. In the present studies, the difference between $\mathrm{AFT}_{4}$ in normal and sick patients was small and would not have achieved statistical 


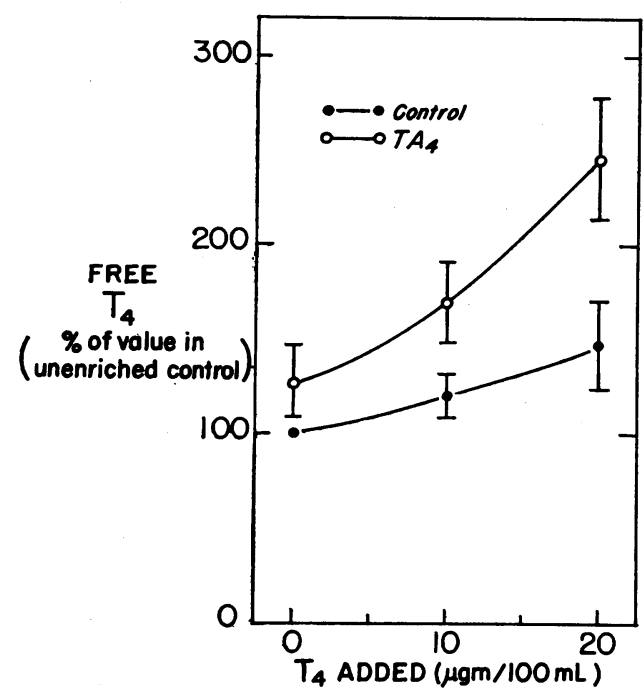

Fig. 2. EFFECT OF ENRICHING NORMAL SERUM WITH THYROXINE $\left(T_{4}\right)$ AND $3,5,3^{\prime}, 5^{\prime}$-TETRAIODOTHYROACETIC ACID (TA4) ON THE PROPORTION OF FREE $T_{4}$. Open circles indicate sera enriched with $466 \mu \mathrm{g}$ per $100 \mathrm{ml}$ of $\mathrm{TA}_{4}$, a concentration shown to inhibit completely the binding of $\mathrm{T}_{4}$ by thyroxine-binding prealbumin (18). Values shown represent mean \pm standard deviation of results in four separate experiments.

significance but for the large group of normal patients studied.

In a single patient with an idiopathic decrease in thyroxine-binding globulin (TBG), reported elsewhere in detail (4), $\mathrm{PFT}_{4}$ was increased to 0.120 , but because the PBI was low $(2.0 \mu \mathrm{g}$ per $100 \mathrm{ml}), \mathrm{AFT}_{4}$ was within the normal range $(3.67 \mathrm{~m} \mu \mathrm{g}$ per $100 \mathrm{ml})$. In a single patient with an idiopathic increase in TBG (17), $\mathrm{PFT}_{4}(0.025)$ was decreased into the range of normal pregnancy, and PBI was elevated, with the result that $\mathrm{AFT}_{4}$ (3.67 $\mathrm{m} \mu \mathrm{g}$ per $100 \mathrm{ml}$ ) was normal. In four male patients treated with diethylstilbestrol, $40 \mathrm{mg}$ daily for 3 weeks, values for $\mathrm{PFT}_{4}$ averaged 0.022 , but $\mathrm{PBI}$ was elevated, and the mean $\mathrm{AFT}_{4}$ (3.72 $\mathrm{m} \mu \mathrm{g}$ per $100 \mathrm{ml}$ ) was within the normal range.

Effect of enriching normal and abnormal sera with stable $T_{4}$. Experiments were performed to determine the effect on $\mathrm{PFT}_{4}$ of enriching normal sera with concentrations of $T_{4}$ ranging between 5 and $20 \mu \mathrm{g}$ per $100 \mathrm{ml}$. In seven experiments, a distinct but gradual increase in the $\mathrm{PFT}_{4}$ occurred over this range of enrichment, and values of $\mathrm{PFT}_{4}$ in the most highly enriched samples averaged $153 \pm 35 \%$ of those obtained in unenriched speci- mens. Nevertheless, despite the fact that PBI values in enriched specimens were at least as high as those found in patients with thyrotoxicosis, values for $\mathrm{PFT}_{4}$ in $\mathrm{T}_{4}$-enriched normal sera were well below those usually found in the sera of thyrotoxic patients.

To investigate this apparent discrepancy, two additional groups of experiments were performed. In the first, samples of normal sera were enriched with 3,5,3',5'-tetraiodothyroacetic acid $\left(\mathrm{TA}_{4}\right)$ to a concentration of $466 \mu \mathrm{g}$ per $100 \mathrm{ml}$, a concentration shown earlier to prevent completely binding of $\mathrm{T}_{4}$ by thyroxine-binding prealbumin (TBPA) (18). After addition of $\mathrm{I}^{131}-\mathrm{T}_{4}$, values for $\mathrm{PFT}_{4}$ were determined. In 20 such experiments, $\mathrm{PFT}_{4}$ in $\mathrm{TA}_{4}$-enriched sera averaged $147 \pm$ $41 \%$ of values in unenriched controls. Experiments were then performed to compare the effect of progressive loading with stable $\mathrm{T}_{4}(0,10$, and $20 \mu \mathrm{g}$ per $100 \mathrm{ml})$ on the $\mathrm{PFT}_{4}$ of sera with and without added $\mathrm{TA}_{4}(466 \mu \mathrm{g}$ per $100 \mathrm{ml})$. Values for $\mathrm{PFT}_{4}$ were determined in duplicate, and a portion of each sample was also subjected to filter paper electrophoretic analysis. In sera containing $\mathrm{TA}_{4}$, electrophoretic analysis revealed no binding of $\mathrm{T}_{4}$ by TBPA, regardless of whether stable $\mathrm{T}_{4}$ had also been added. Here, the proportion of $\mathrm{I}^{131}$ $\mathrm{T}_{4}$ bound by both TBG and albumin was greater than in sera containing no $\mathrm{TA}_{4}$. In sera containing $\mathrm{TA}_{4}$, progressive enrichment with $\mathrm{T}_{4}$ produced displacement of $\mathrm{I}^{131}-\mathrm{T}_{4}$ from $\mathrm{TBG}$ to albumin. Far less displacement of $\mathrm{I}^{131}-\mathrm{T}_{4}$ to albumin was produced by $\mathrm{T}_{4}$ in sera containing no $\mathrm{TA}_{4}$; in these specimens, $\mathrm{I}^{131}-\mathrm{T}_{4}$ displaced from $\mathrm{TBG}$ became associated largely with TBPA. In four experiments shown in Figure 2, enrichment of control sera with $\mathrm{T}_{4}$ produced a gradual increase in $\mathrm{PFT}_{4}$. In the absence of added $\mathrm{T}_{4}$, sera containing $\mathrm{TA}_{4}$ displayed higher values for $\mathrm{PFT}_{4}$ than did controls, and values for $\mathrm{PFT}_{4}$ increased more sharply in the former when $\mathrm{T}_{4}$ was added.

In the second group of experiments, the effect of enrichment with stable $\mathrm{T}_{4}$ on the $\mathrm{PFT}_{4}$ in the serum of normal and sick patients was compared. In the latter samples, in which binding of $\mathrm{T}_{4}$ by TBPA was greatly reduced, enrichment with stable $\mathrm{T}_{4}$ to a maximal concentration of $20 \mu \mathrm{g}$ per $100 \mathrm{ml}$ increased $\mathrm{PFT}_{4}$ far more than in comparably enriched normal sera. In two experiments performed in duplicate, values for $\mathrm{PFT}_{4}$ in 
normal sera were increased $24 \%$ by enrichment with stable $\mathrm{T}_{4}$. In sera of sick patients, comparable enrichment increased $\mathrm{PFT}_{4}$ by $102 \%$. Thus, values for $\mathrm{PFT}_{4}$ in $\mathrm{T}_{4}$-enriched sera of sick patients averaged 2.7 times those found in comparably enriched normal controls.

The per cent of free $T_{s}$ in normal serum $\left(P F T_{3}\right)$. In 12 sera from normal subjects, $\mathrm{PFT}_{4}$ and $\mathrm{PFT}_{3}$ were concomitantly assessed. In all instances, values for $\mathrm{PFT}_{3}$ were much larger than for $\mathrm{PFT}_{4}$, the ratio of the two averaging $9.6 \pm 2.4$.

\section{Discussion}

The present report describes a simple, reproducible method for measuring the proportion of free $T_{4}$ and other labeled thyroid hormones in human serum. This method appears to have major advantages over those that have previously been fully described $(5,6)$. The first phase of the present method, equilibrium dialysis of the test serum, is essentially the same as that described by Sterling and Hegedus and would be expected, therefore, to share any shortcomings with the method described by those workers (5). In the present studies, a substantial proportion of the $\mathrm{I}^{131}-\mathrm{T}_{4}$ was found to be adsorbed to the tube in which equilibrium dialysis was carried out. Failure of Sterling and Hegedus to find such adsorption can probably be ascribed to the indirect method they employed to study this question. Adsorption is not progressive, however, since the studies indicate that an equilibrium is established between the test serum, the dialyzate, and the wall of the cellulose nitrate tube. Nevertheless, such adsorption, in effect, lowers the total concentration of $\mathrm{T}_{4}$ in the system and would be expected to decrease values for $\mathrm{PFT}_{4}$ somewhat. From the rather low rate of increase in $\mathrm{PFT}_{4}$ caused by addition of $\mathrm{T}_{4}$ (Figure 2 ), however, it may be presumed that this effect would be small.

Values for the $\mathrm{PFT}_{4}$ in normal serum obtained by the present method are substantially lower than those reported in the original method of Sterling and Hegedus, in which resin columns were employed to separate $\mathrm{I}^{131}$-iodide from $\mathrm{I}^{131}-\mathrm{T}_{4}$ in the equilibrium dialyzate (5). The higher values those workers obtained can probably be ascribed to incomplete separation of $\mathrm{I}^{131}-\mathrm{T}_{4}$ from the preponderating $\mathrm{I}^{131}$-iodide in dialyzates, especially as our values are very similar to those obtained with the magnesium precipitation method, which Sterling and Brenner have recently described in abstract form (19).

Another difference between the present results and those reported by Sterling and Hegedus is that these workers found little or no increase in $\mathrm{PFT}_{4}$ when normal serum was enriched with stable $T_{4}$ in concentrations as high as $20 \mu \mathrm{g}$ per $100 \mathrm{ml}$. In the present studies, such enrichment of normal serum led to clearly increased values for $\mathrm{PFT}_{4}$. The magnitude of the increase was quite variable, however, especially at the highest concentration of $\mathrm{T}_{4}$ employed. At this concentration, the total thyroxine in the system would be approximately 28 $\mu \mathrm{g}$ per $100 \mathrm{ml}$, a value at the upper limit or in excess of the normal range for the $\mathrm{T}_{4}$-binding capacity of TBG (1). Thus, the sera in which $\mathrm{PFT}_{4}$ increased most markedly at this level of enrichment may have been those in which the binding capacity of TBG had been exceeded. Walfish, Britton, Volpé, and Ezrin placed a similar interpretation upon the rapid increase in the in vitro red cell uptake of labeled $\mathrm{T}_{3}$ that occurs as serum is enriched with $T_{4}$ in concentrations similar to those herein employed (20).

The second previous method for directly estimating the $\mathrm{PFT}_{4}$ in serum is that described by Oppenheimer and colleagues (6). This method involves the equilibrium dialysis of extensively diluted samples of serum. Such dilution increases the proportion of unbound $T_{4}$ in the system and thus makes possible adequate separation of $\mathrm{I}^{131}-\mathrm{T}_{4}$ from $\mathrm{I}^{131}$-iodide by trichloroacetic acid precipitation of the dialyzate after addition of protein. In their original report, Oppenheimer and colleagues made the assumption that absolute values for $\mathrm{PFT}_{4}$ in dilute sera would be increased above those in undiluted sera by a factor equal to the extent of dilution $(6),{ }^{7}$ and in a later communication an extensive mathematical analysis was presented to support this assumption (21). Thus, the corrected values for the $\mathrm{PFT}_{4}$ of undiluted serum

\footnotetext{
${ }^{7}$ Oppenheimer and colleagues did not actually present values for $\mathrm{PFT}_{4}$. Rather, they calculated a "dialyzable fraction (DF)," representing the fraction of total $T_{4}$ in their entire system that was dialyzable. From the published conditions, however, values for corrected $\mathrm{PFT}_{4}$ analogous to those herein described can readily be calculated.
} 
could be calculated as the quotient of the $\mathrm{PFT}_{4}$ in diluted serum divided by the dilution factor. In these studies, no difference was found between corrected values for $\mathrm{PFT}_{4}$ in samples diluted $1: 8$, $1: 30$, and $1: 150$. Although values for $\mathrm{PFT}_{4}$ in undiluted sera, assayed by ultrafiltration, were consistently higher than corrected values in dilute sera, this was ascribed to inaccuracies of the ultrafiltration technique (21). The present findings suggest an alternative explanation, that use of dilute sera yields corrected values for the $\mathrm{PFT}_{4}$ of undiluted sera, which are spuriously low. Thus, concomitant analyses of undiluted and variously diluted sera by the present technique revealed that dilution of serum by as little as 1:5 decreased values for corrected $\mathrm{PFT}_{4}$ by approximately $50 \%$, although no further effect was evident at higher dilutions. It is probably significant, furthermore, that the average value for $\mathrm{AFT}_{4}$ in normal sera reported by Oppenheimer and colleagues is approximately $50 \%$ lower than that obtained by the present technique. In view of both the apparent effects of diluting serum and the ease and reliability with which the resin dialysis technique separates $\mathrm{I}^{131}$-iodide and $\mathrm{I}^{131}-\mathrm{T}_{4}$, analysis of diluted serum seems less desirable than use of undiluted specimens.

The concept that the interaction between $T_{4}$ and the thyroxine-binding proteins of serum is a reversible binding equilibrium would dictate that increases in the absolute concentration of $T_{4}$, such as are produced by in vitro enrichment, should increase the $\mathrm{PFT}_{4}(1)$. The failure of other workers to note appreciable increases over a physiologic range of $T_{4}$ concentrations was puzzling in this light (5), but the present data, which do demonstrate such increases in $\mathrm{PFT}_{4}$, tend to support traditional concepts. Nevertheless, values for $\mathrm{PFT}_{4}$ in normal sera in which the $\mathrm{T}_{4}$ concentrations were increased to levels characteristic of thyrotoxicosis were lower than values for $\mathrm{PFT}_{4}$ usually seen in sera from patients with this disease. This suggests that an increase in hormonal concentration cannot alone account for the high values for $\mathrm{PFT}_{4}$ that patients with thyrotoxicosis often demonstrate. Conceivably, a decrease in the activity of the thyroxine-binding proteins could accentuate the increase in $\mathrm{PFT}_{4}$ produced by an increased $\mathrm{T}_{4}$ concentration. The $\mathrm{T}_{4}$-binding capacity of TBG in thyrotoxicosis is most often found to be normal or slightly increased $(1,6$, 20). It seemed reasonable, therefore, to suspect that the other major $\mathrm{T}_{4}$-binding protein, TBPA, might be implicated. A decreased binding capacity of TBPA in many patients with thyrotoxicosis was first noted by Richards, Dowling, and Ingbar (22) and has recently been confirmed by Oppenheimer and his colleagues (6). The former workers, employing red cell uptakes of $\mathrm{I}^{131}-\mathrm{T}_{4}$ and $\mathrm{I}^{131}-\mathrm{T}_{3}$, found that $\mathrm{T}_{4}$-enrichment of sera from sick patients with low $\mathrm{T}_{4}$-binding capacities of TBPA produced uptake values within the thyrotoxic range, but did not do so in sera with normal TBPA. In the present studies, this relationship was directly tested and verified in two ways. First, enrichment of sick sera with low $\mathrm{T}_{4}$-binding capacities of TBPA produced significantly greater increases in $\mathrm{PFT}_{4}$ than in normal sera, and values in the thyrotoxic range were obtained. Second, when $\mathrm{T}_{4}$-binding by TBPA was obliterated by the addition of $\mathrm{TA}_{4}, \mathrm{PFT}_{4}$ in unenriched sera increased to values similar to those seen in sick patients whose binding of $\mathrm{T}_{4}$ by TBPA was comparably low. When sera containing $\mathrm{TA}_{4}$ were enriched with $T_{4}$ to concentrations similar to those found in thyrotoxicosis, a sharper rise in $\mathrm{PFT}_{4}$ than in normal sera was noted, and values for $\mathrm{PFT}_{4}$ in the thyrotoxic range were found. These findings suggest that the pronounced increase in $\mathrm{PFT}_{4}$ noted in the serum of some patients with thyrotoxicosis may be due to both an increase in the concentration of the ligand (i.e., $\mathrm{T}_{4}$ ) and a decrease in available binding sites through a reduction in the $\mathrm{T}_{4}$-binding capacity of TBPA. The possibility that other, as yet undiscovered, factors may be operative cannot be excluded, however.

By the same token, decreased $T_{4}$ binding by TBPA would appear to contribute at least in part to the increased values for $\mathrm{PFT}_{4}$ noted in sera from patients with a variety of severe illnesses. Such changes, first evident in the red blood cell uptake studies of Richards and co-workers (22), have recently been confirmed by dialysis of dilute serum by Oppenheimer and co-workers (6). Similar changes in TBPA have been noted in patients severely ill with myxedema, and this factor may account for the present observations that values for $\mathrm{PFT}_{4}$ in patients with myxedema are not infrequently in the normal range. These direct measurements are consistent with the several re- 
ports that indirect indexes of $\mathrm{PFT}_{4}$, such as resin and blood cell uptakes, are often unexpectedly high in patients with myxedema (23-29).

In the present studies, despite considerable variability, values for $\mathrm{AFT}_{4}$ in patients with nonspecific illness were significantly increased as a result of increases in $\mathrm{PFT}_{4}$. This change in $\mathrm{AFT}_{4}$ contrasts strikingly with the normal values for $\mathrm{AFT}_{4}$ in those disorders in which $\mathrm{PFT}_{4}$ is altered as a result of a primary, uncomplicated change in $\mathrm{T}_{4}$ binding. Examples of the latter are patients with idiopathic increase or decrease in TBG and patients given estrogen. In such patients, total hormonal concentration varies directly with the change in $T_{4}$ binding so that the alteration in $\mathrm{PFT}_{4}$ is overcome and $\mathrm{AFT}_{4}$ is normal. In the patients with nonspecific illness, in contrast, values for PBI were somewhat lower than normal, but this decrease was insufficient to prevent a significant increase in $\mathrm{AFT}_{4}$ for the group as a whole. One may wonder, therefore, whether in such patients homeostasis is driven to provide increased quantities of physiologically active hormone to the peripheral tissues. Such a hypothesis is consistent with observations that demonstrate an increased rate of $\mathrm{T}_{4}$ degradation in both febrile and afebrile patients with a variety of illnesses (30, $31)$.

It is generally considered that the $T_{4}$ in the plasma turns over at a relatively slow rate, and this is true when the entire circulating hormone is considered. $\mathrm{T}_{4}$ clearance rates from the plasma in normal adults average approximately $1 \mathrm{~L}$ per day (32). If it is true, however, that only the free $\mathrm{T}_{4}$ is available to the cells, then the value for $\mathrm{PFT}_{4}$ would indicate that the clearance of free $\mathrm{T}_{4}$ normally averages approximately $2,000 \mathrm{~L}$ per day or more than $80 \mathrm{~L}$ per hour. Turnover of free $\mathrm{T}_{4}$ is thus seen to be exceedingly rapid, and the profound effect of hormonal binding on over-all kinetics of hormonal metabolism is evident.

Finally the present studies have provided the first data concerning the relationship between $\mathrm{PFT}_{4}$ and $\mathrm{PFT}_{3}$, the latter being nine to ten times the former. The majority of data in the literature indicates that $\mathrm{I}^{131}-\mathrm{T}_{3}$, in vivo, turns over at the rate of approximately $55 \%$ per day (33-37), although one report indicates that the rate of turnover may be somewhat slower (38). Although few, if any, data are available concerning the vol- ume of distribution of $T_{3}$, inspection of published observations indicates that the distribution space may be approximately $12 \mathrm{~L}(37,38)$. This value is only slightly greater than that for $T_{4}(32)$, a conclusion consonant with the suggestion that the per cent of free hormone is a major determinant of the intracellular component of its distribution space (2). Thus, although $\mathrm{PFT}_{3}$ is approximately ten times $\mathrm{PFT}_{4}$, approximately $99.95 \%$ and $99.50 \%$ of $\mathrm{T}_{4}$ and $\mathrm{T}_{3}$ in the blood are protein bound, respectively.

From the foregoing figures it may be estimated that the over-all clearance of $T_{3}$ in adults is approximately $7 \mathrm{~L}$ daily. Thus the clearance of free $\mathrm{T}_{3}$, which comprises approximately $0.50 \%$ of the total $\mathrm{T}_{3}$, would be approximately $1,400 \mathrm{~L}$ per day, a value less than the calculated rate of clearance of free $T_{4}$. This finding may be related to a lesser ability of cellular mechanisms to degrade $T_{3}$, since most in vitro deiodinating systems for thyroid hormones degrade $T_{3}$ less rapidly than $T_{4}(39-41)$.

\section{Summary}

A simple, reproducible method has been developed and evaluated for measuring the per cent of free thyroid hormone in human serum $\left(\mathrm{PFT}_{4}\right)$. In normal patients, the free thyroxine $\left(\mathrm{T}_{4}\right)$ in serum averaged $0.050 \%$ of the total, whereas the proportion of free triiodothyronine was nine to ten times as large. Significant decreases in $\mathrm{PFT}_{4}$ were found in the serum of patients with myxedema or pregnancy and significant increases in patients with thyrotoxicosis or a variety of severe nonthyroidal illnesses (sick patients). In the several diagnostic categories, however, considerable overlap of individual values with the normal range was observed.

Values for the absolute concentration of free thyroxine in serum were decreased in patients with myxedema and increased in patients with thyrotoxicosis. Small but significant decreases and increases, respectively, were found in absolute concentrations of free $T_{4}$ in the sera of pregnant and sick patients.

Use of dilute, rather than whole, serum was found to yield spuriously low values for the per cent of free $T_{4}$. Enrichment of normal sera with sufficient thyroxine to bring protein-bound iodine into the thyrotoxic range increased $\mathrm{PFT}_{4}$. Nev- 
ertheless, values for the per cent of free $T_{4}$ in enriched specimens of normal serum were less than those usually seen in patients with thyrotoxicosis. Enrichment with thyroxine of sera in which thyroxine binding by prealbumin (TBPA) was decreased, either as a result of systemic illness or of the addition of tetraiodothyroacetic acid, produced far greater increases in the per cent of free $T_{4}$ than it did in normal serum, and values in the thyrotoxic range resulted.

The data provide further evidence that TBPA contributes significantly to thyroxine binding in normal serum and suggest that the increased values for the per cent of free $T_{4}$ found in serum from thyrotoxic patients are due, at least in part, both to an increase in thyroxine concentration and a decrease in TBPA.

\section{Acknowledgment}

The authors are indebted to Mrs. Ann King for excellent technical assistance.

\section{References}

1. Robbins, J., and J. E. Rall. Proteins associated with the thyroid hormones. Physiol. Rev. 1960, 40, 415.

2. Ingbar, S. H., and N. Freinkel. Regulation of the peripheral metabolism of the thyroid hormones. Recent Progr. Hormone Res. 1960, 16, 353.

3. Beierwaltes, W. H., and J. Robbins. Familial increase in the thyroxine-binding sites in serum alpha globulin. J. clin. Invest. 1959, 38, 1683.

4. Ingbar, S. H. Clinical and physiological observations in a patient with an idiopathic decrease in the thyroxine-binding globulin of plasma. J. clin. Invest. 1961, 40, 2053.

5. Sterling, K., and A. Hegedus. Measurement of free thyroxine concentration in human serum. J. clin. Invest. 1962, 41, 1031.

6. Oppenheimer, J. H., R. Squef, M. I. Surks, and H. Hauer. Binding of thyroxine by serum proteins evaluated by equilibrium dialysis and electrophoretic techniques. Alterations in nonthyroidal illness. J. clin. Invest. 1963, 42, 1769.

7. Lee, N. D., R. J. Henry, and O. J. Golub. Determination of the free thyroxine content of serum. J. clin. Endocr. 1964, 24, 486.

8. Hamolsky, M. W., M. Stein, and A. S. Freedberg. The thyroid hormone-plasma protein complex in man. II. A new in vitro method for study of "uptake" of labelled hormonal components by human erythrocytes. J. clin. Endocr. 1957, 17, 33.

9. Mitchell, M. L. Resin uptake of radiothyroxine in sera from nonpregnant and pregnant women. J. clin. Endocr. 1958, 18, 1437.
10. Christensen, L. K. A method for the determination of free, nonprotein bound thyroxine in serum. Scand. J. clin. Lab. Invest. 1959, 11, 326.

11. Osorio, C., D. J. Jackson, J. M. Gartside, and A. W. G. Goolden. The assessment of free thyroxine in plasma. Clin. Sci. 1962, 23, 525.

12. Ingbar, S. H., L. E. Braverman, N. Dawber, and G. Y. Lee. A simple method for measuring the free thyroid hormone in serum. Clin. Res. 1964, 12, 271.

13. Ingbar, S. H., and N. Freinkel. Concentration gradients for radioiodide in unblocked thyroid glands of rats: effect of perchlorate. Endocrinology 1956, 58, 95.

14. Benotti, J., and N. Benotti. Protein-bound iodine, total iodine and butanol extractable iodine by partial automation. Clin. Chem. 1963, 9, 408.

15. Snedecor, G. W. Statistical Methods Applied to Experiments in Agriculture and Biology, 5th ed. Ames, Iowa, Iowa State College Press, 1956.

16. Braverman, L. E., and S. H. Ingbar. The metabolism of thyroid hormones as related to protein binding. J. chron. Dis. 1961, 14, 484.

17. Ingbar, S. H., C. Waterhouse, and P. Cushman. Observations on the nature of the underlying disorder and the occurrence of associated plasma transport abnormalities in a patient with an idiopathic increase in the plasma thyroxine-binding globulin. J. clin. Invest. 1964, 43, 2266.

18. Ingbar, S. H. Observations concerning the binding of thyroid hormones by human serum prealbumin. J. clin. Invest. 1963, 42, 143.

19. Sterling, K., and M. A. Brenner. Determination of free thyroxine in serum by magnesium precipitation. Clin. Res. 1964, 12, 464.

20. Walfish, P. G., A. Britton, R. Volpé, and C. Ezrin. Quantitative plasma binding capacity studies of thyroxine-binding globulin by use of a modification of the erythrocyte $l$-triiodothyronine- $\mathrm{I}^{131}$ uptake test. J. clin. Endocr. 1962, 22, 178.

21. Oppenheimer, J. H., and M. I. Surks. Determination of free thyroxine in human serum: a theoretical and experimental analysis. J. clin. Endocr. 1964, 24, 785.

22. Richards, J. B., J. T. Dowling, and S. H. Ingbar. Alterations in the plasma transport of thyroxine in sick patients and their relation to the abnormality in Graves' disease. J. clin. Invest. 1959, 38, 1035.

23. Mitchell, M. L., A. B. Harden, and M. E. O'Rourke. The in vitro resin sponge uptake of triiodothyronine- $\mathrm{I}^{131}$ from serum in thyroid disease and in pregnancy. J. clin. Endocr. 1960, 20, 1474.

24. Friis, T. In vitro uptake of ${ }^{131} \mathrm{I}$ labelled L-triiodothyronine by human erythrocytes. Acta Endocr. (Kbh.) 1960, 33, 117.

25. Woldring, M. G., A Bakker, and H. Doorenbos. The uptake of ${ }^{131} \mathrm{I}$ triiodothyronine by resin. An in vitro test of thyroid function. Acta Endocr. (Kbh.) 1961, 37, 607. 
26. Sterling, K., and M. Tabachnick. Resin uptake of $\mathrm{I}^{131}$-triiodothyronine as a test of thyroid function. J. clin. Endocr. 1961, 21, 456.

27. Shapiro, B., and J. L. Rabinowitz. A chromatographic method utilizing Sephadex for the separation of free iodide, protein-bound and unbound triidothyronine in sera. A) Clinical correlations with the Hamolsky T-3-RBC uptake method (108 cases). J. nucl. Med. 1962, 3, 417.

28. Sodee, D. B. Clinical usefulness of the $\mathrm{I}^{131}$ triiodothyronine erythrocyte uptake test. J. Amer. med. Ass. 1963, 185, 136.

29. McAdams, G. B., and R. F. Reinfrank. Resin sponge modification of the $\mathrm{I}^{131} \mathrm{~T} 3$ test. J. nucl. Med. 1964, 5, 112.

30. Sterling, K., and R. B. Chodos. Radiothyroxine turnover studies in myxedema, thyrotoxicosis and hypermetabolism without endocrine disease. $\mathrm{J}$. clin. Invest. 1956, 35, 806.

31. Braverman, L. E., and S. H. Ingbar. Unpublished observations.

32. Ingbar, S. H., and N. Freinkel. Simultaneous estimation of rates of thyroxine degradation and thyroid hormone synthesis. J. clin. Invest. 1955, 34, 808.

33. Ruegamer, W. R., and R. B. Chodos. Diiodotyrosine and triiodothyronine metabolism in liver disease. Clin. Res. 1956, 4, 145.

34. Hales, I. B., and B. M. Dobyns. The metabolism of triiodothyronine in Graves' disease. J. clin. Endocr. $1960,20,68$

35. Hollander, C. S., V. V. Odak, and S. P. Asper, Jr. A study of the optical isomers of triiodothyronine. Clin. Res. 1961, 9, 181.

36. Kuhl, W. J., I. S. Halper, and R. M. Dowben. Thyroxine and triiodothyronine turnover studies in dystrophia myotonica. J. clin. Endocr. 1961, 21, 1592.

37. Wiswell, J. G., and V. Coronho. Disappearance of $\mathrm{I}^{131}$-triiodothyronine from the plasma in the presence of fever. J. clin. Endocr. 1962, 22, 657.

38. Sterling, K., J. C. Lashof, and E. B. Man. Disappearance from serum of $\mathrm{I}^{181}$-labeled $\mathrm{L}$-thyroxine and L-triiodothyronine in euthyroid subjects. J. clin. Invest. 1954, 33, 1031.

39. Yamazaki, E., and D. W. Slingerland. The in vitro metabolism of thyroxine, triiodothyronine and their acetic and propionic acid analogues. Endocrinology 1959, 64, 126.

40. Galton, V. A., and S. H. Ingbar. Observations on the relation between the action and the degradation of thyroid hormones as indicated by studies in the tadpole and the frog. Endocrinology 1962, 70, 622.

41. Braverman, L. E., and S. H. Ingbar. Effects of propylthiouracil and thiouracil on the metabolism of thyroxine and several of its derivatives by rat kidney slices in vitro. Endocrinology 1962, 71, 701. 